\title{
An Indium Tin Oxide-Free Polymer Solar Cell on Flexible Glass
}

\author{
Nadia Formica, ${ }^{\dagger}$ Paola Mantilla-Perez, ${ }^{\dagger}$ Dhriti S. Ghosh, ${ }^{*}{ }^{\dagger}$ Davide Janner, ${ }^{\dagger}$ Tong Lai Chen, ${ }^{\dagger}$ \\ Minghuang Huang, ${ }^{\ddagger}$ Sean Garner, ${ }^{\ddagger}$ Jordi Martorell, ${ }^{\dagger, \S}$ and Valerio Pruneri ${ }^{\dagger, \|}$ \\ ${ }^{\dagger}$ ICFO-Institut de Ciències Fotòniques Mediterranean Technology Park, 08860 Castelldefels, Barcelona, Spain \\ ${ }^{\ddagger}$ Corning Inc., Sullivan Park, Corning, New York 14831, United States \\ ${ }^{\S}$ Departament de Física i Enginyeria Nuclear, Universitat Politècnica de Catalunya, Terrassa, Spain \\ "ICREA-Institució Catalana de Recerca i Estudis Avançats, 08010 Barcelona, Spain
}

Supporting Information

\begin{abstract}
Future optoelectronic devices and their low-cost roll-to-roll production require mechanically flexible transparent electrodes (TEs) and substrate materials. Indium tin oxide (ITO) is the most widely used TE because of its high optical transmission and low electrical sheet resistance. However, ITO, besides being expensive, has very poor performance under mechanical stress because of its fragile oxide nature. Alternative TE materials have thus been sought. Here we report the development of a multilayer $\mathrm{TiO}_{2} / \mathrm{Ag} / \mathrm{Al}$-doped $\mathrm{ZnO}$ TE structure and an ITO-free polymer solar cell (PSC) incorporating it. Electro-optical performances close to those of ITO can be achieved for the proposed TE and corresponding PSC with an additional advantage in their mechanical flexibility, as demonstrated by the fact that the cell efficiency maintains $94 \%$ of its initial value (6.6\%) after 400 cycles of bending, with 6 and $3 \mathrm{~cm}$ maximum and minimum radii, respectively. Instead of common plastic materials, our work uses a very thin $(0.14 \mathrm{~mm})$ flexible glass substrate with several benefits, such as the possibility of high-temperature processes, superior antipermeation properties against oxygen and moisture, and improved film adhesion.
\end{abstract}

KEYWORDS: ultrathin, transparent electrode, flexible glass, ITO-free, polymer solar cell

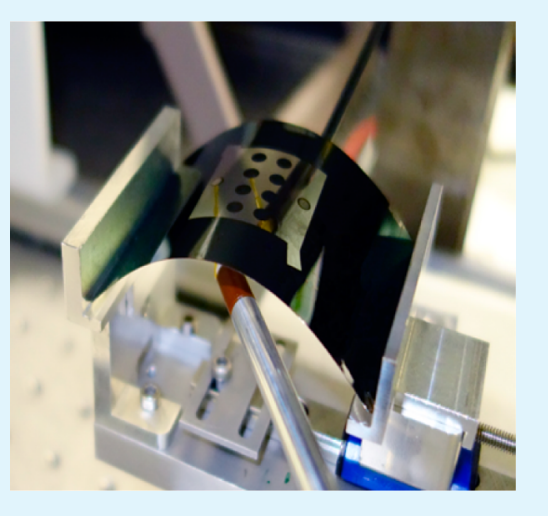

\section{INTRODUCTION}

Polymer solar cells (PSCs) have the potential to supply a significant amount of the world's energy provided from renewable resources. Moreover, they have several advantages over costly and complex solar cells that are widely in use today. ${ }^{1,2}$ PSCs use inexpensive materials, are easily processed and lightweight, and can be made mechanically flexible. ${ }^{3}$ Two kinds of classic conjugated polymers, poly(phenylenevinylene)s (PPV) and polythiophenes (PTs), are broadly used in photovoltaic cells. Among the PPV-based materials, $\mathrm{MEH}$ PPV and MDMO-PPV are employed as electron donor materials in solar cells, and they exhibited much similar photovoltaic properties. ${ }^{4,5}$ A photon conversion efficiency (PCE) of $2 \%$ has been reported by using MEH-PPV. However, the performances of the solar cells based on MEH-PPV and MDMO-PPV are limited because of the sizable mismatch between their absorption spectra and the solar irradiation spectrum. In comparison with them, P3HT, one of the derivatives of poly(3-alkylthiophene), exhibits a lower band gap, a broader absorption band, and better hole mobility, and therefore, this conjugated polymer showed much better photovoltaic properties. ${ }^{6}$ Recently, many more high-performance polymers with a low band gap such as poly[ $\mathrm{N}-9^{\prime \prime}$ heptadecanyl-2,7-carbazole-alt-5,5-(4', $7^{\prime}$-di-2-thienyl-2', $1^{\prime}, 3^{\prime}$ benzothiadiazole)] (PCDTBT), poly(4,8-bis-substituted- benzo[1,2-b:4,5-b0] dithiophene-2,6-diyl-alt-4-substitutedthieno[3,4b]thiophene-2,6-diyl) (PBDTTT), and benzodithiophene polymer (PTB7) have been developed to better harvest the solar spectrum, especially in the region of $1.4-1.9 \mathrm{eV}$. PTB7 has allowed the fabrication of photovoltaic devices with an efficiency of $>8 \%$. On the other hand, the most efficient known acceptor materials are fullerene and fullerene derivatives, in particular [6,6]-phenyl-C-61-butyric acid methyl ester $\left(\mathrm{PC}_{61} \mathrm{BM}\right)$ and $[6,6]$-phenyl-C-71-butyric acid methyl ester $\left(\mathrm{PC}_{71} \mathrm{BM}\right){ }^{7,8}$

Materials innovation is one of the major forces currently driving the performance of PSCs, but device optimization by utilizing different architectures or a controlled morphology of active layers is also a successful strategy for improving the PCE of PSCs. $^{9-18}$

However, current state-of-the-art PSCs are typically fabricated on substrates coated with indium tin oxide (ITO) transparent electrodes (TEs), and this represents an obstacle for the successful commercialization of PSCs. ${ }^{19-24}$ In fact, ITO is not an ideal TE material with regard to low cost and mechanical flexibility. ${ }^{25,26}$ Scarce supplies and increasing

Received: October 17, 2014

Accepted: February 5, 2015

Published: February 5, 2015 
demand have led to substantial indium price fluctuations. ${ }^{27,28}$ The fragility of ITO under bending makes also it unsuitable for flexible devices. Additionally, to obtain high-quality ITO, temperatures in the range of $150-300{ }^{\circ} \mathrm{C}$ are required, this posing sometimes severe restrictions on other materials forming the devices, including polymer substrates. Therefore, replacing ITO with other TEs' materials is still a challenge that would have an impact not only on PSCs but also on a wider range of similar devices. ${ }^{29}$ There are several materials that emerge as replacements for ITO, e.g., intrinsically conductive polymers such as poly(3,4-ethylenedioxythiophene):poly(styrenesulfonate) (PEDOT:PSS), thin (10-20 nm in thickness) metal films, wide band gap semiconductors, such as $\mathrm{Al}$ doped $\mathrm{ZnO}(\mathrm{AZO}){ }^{30}$ combinations of thin metal films with $\mathrm{AZO}$, and polymers containing metal nanostructures such as meshes of metal nanowires. ${ }^{31-40}$ To achieve electrical sheet resistance $\left(R_{\mathrm{S}}\right)$ values comparable to those of ITO (15-20 $\Omega$ / sq), PEDOT:PSS has also been combined with thin metal grids (with a thickness of generally $<100 \mathrm{~nm}$ ) using various processing techniques. ${ }^{41-43}$ Because of its superior optical transmittance, electrical conductivity, atomic thickness, and excellent resistance to chemicals and solvents, graphene has also been recognized as an important material for TEs in optoelectronic devices. $^{44,45}$ It has been used as a TE for both organic and dye-sensitized solar cells by many research groups. However, the research is still in the early stages, and the performances of such devices are not as good as those of the devices with ITO electrodes because the conductivities of graphene electrodes are relatively low. ${ }^{46-48}$ Despite that, because its flexibility is much better than that of ITO, graphene is suitable for applications in flexible electronics. ${ }^{49}$ Graphene oxide (GO) and chemically reduced graphene oxide (rGO) films on polyethylene terephthalate (PET) polymer have been reported as flexible substrates for new transparent optoelectronic devices. ${ }^{50}$ In the field of organic photovoltaics, the highest PCE incorporating rGO is $1.1 \% .{ }^{51}$ More recently, highperformance flexible PSCs with a PCE of $8.7 \%$ on a PET substrate precoated with ITO were developed by using the $\mathrm{P} 3 \mathrm{HT}: \mathrm{PC}_{61} \mathrm{BM}$ system. ${ }^{52}$ Although this is the best achievement in terms of PCE for PSCs on a polymeric substrate, as far as we know, the main limitation is represented by the use of costly ITO.

Alternatively, another ITO-free TE is ultrathin $(<10 \mathrm{~nm}$ thick) metal films (UTMFs), as they combine high electrical conductivity, large mechanical flexibility, the possibility of lowtemperature processing, and low cost. UTMFs can also be scaled on large areas with straightforward sputtering deposition processes. ${ }^{53-55}$ When UTMFs are embedded between two transparent conductive oxide (TCO) layers, the final multilayer electrode exhibits improved electrical and optical properties compared to those of a single UTMF. ${ }^{56}$

In this paper, we investigate a multilayer $\mathrm{TiO}_{2} / \mathrm{Ag} / \mathrm{AZO}$ based TE on mechanically flexible Corning Willow Glass substrates with a thickness of $0.140 \mathrm{~mm}$ and its application as a bottom electrode in inverted PSC devices. With respect to conventional flexible polymer substrates [such as PET and polyethylene naphthalate (PEN)], flexible thin glass provides higher optical transmission, lower surface roughness, improved film adhesion, higher processing temperatures, and superior antipermeation properties against oxygen and moisture, while at the same time ensuring sufficient mechanical flexibility, essential for roll-to-roll manufacturing processes. $^{57}$ In fact, several high-temperature processed TEs on flexible glass substrates were compared in terms of bending performance with respect to commercially available ITO-coated polymer films. ${ }^{58}$

\section{EXPERIMENTAL DETAILS}

TE Deposition. Flexible Corning Willow Glass $(0.140 \mathrm{~mm}$ thick and 2 in. $\times 3$ in. square) was used as a substrate. Before TE deposition, the substrates were cleaned in acetone followed by ethanol in an ultrasonic bath, each process lasting $10 \mathrm{~min}$. The substrates were then rinsed in abundant deionized (DI) water and dried with nitrogen gas followed by oxygen plasma for $150 \mathrm{~s}$.

The entire TE structure was prepared by magnetron sputtering without breaking the vacuum. The target-substrate distance was 300 $\mathrm{mm}$. The substrate holder was rotating during deposition. $\mathrm{Ag}$ and $\mathrm{TiO}_{2}$ were deposited in a pure $\mathrm{Ar}$ atmosphere, while $\mathrm{AZO}$ (at $3 \% \mathrm{Al}$ doping) was deposited in an $\mathrm{Ar} / \mathrm{O}_{2}$ mixture (flux ratio of 9:1), all of them at room temperature. A silver $(99.99 \%, 2$ in.) target was used to deposit the Ag films using a dc power of $100 \mathrm{~W}$ and a working pressure of $2 \times 10^{-3}$ Torr. The $\mathrm{TiO}_{2}$ film was deposited in RF mode under the same conditions of the Ag film. The AZO films were grown at an RF power of $150 \mathrm{~W}$. The sputtering chamber was initially evacuated to a base pressure of $10^{-7}$ Torr, and the deposition pressure was maintained at $1.3 \times 10^{-3}$ Torr. Following initial simulation results by using Fresnel matrix formalism, the thickness of the top AZO film was kept at $40 \mathrm{~nm}$ for all structures, while that of the $\mathrm{Ag}$ and $\mathrm{TiO}_{2}$ layers was varied from 6 to $10 \mathrm{~nm}$ and from 23 to $46 \mathrm{~nm}$, respectively.

OPV Fabrication. Willow Glass substrates covered with the $\mathrm{TiO}_{2} /$ $\mathrm{Ag} / \mathrm{AZO} \mathrm{TE}$ were solvent cleaned in acetone, ethanol, and methanol with intermediate DI water baths. The substrates were then dried and treated with ultraviolet radiation and ozone for $10 \mathrm{~min}$. The precursor for the sol-gel $\mathrm{ZnO}$ was prepared by dissolving zinc acetate dehydrate $\left[\mathrm{Zn}\left(\mathrm{CH}_{3} \mathrm{COO}\right)_{2} \cdot 2 \mathrm{H}_{2} \mathrm{O}\right.$, Aldrich, $\left.99.9 \%, 1 \mathrm{~g}\right]$ and ethanolamine $\left(\mathrm{NH}_{2} \mathrm{CH}_{2} \mathrm{CH}_{2} \mathrm{OH}\right.$, Aldrich, 99.5\%, $\left.0.28 \mathrm{~g}\right)$ in 2-methoxyethanol $\left(\mathrm{CH}_{3} \mathrm{OCH}_{2} \mathrm{CH}_{2} \mathrm{OH}\right.$, Aldrich, $\left.99.8 \%, 10 \mathrm{~mL}\right)$ while the mixture was being stirred for at least $12 \mathrm{~h} .{ }^{56}$ Afterward, it was spin-coated on the $\mathrm{TiO}_{2} / \mathrm{Ag} / \mathrm{AZO}$ and annealed in air at $150{ }^{\circ} \mathrm{C}$ for $10 \mathrm{~min}$. The samples were then transferred into a glovebox for further fabrication steps. An active layer of PTB7:PC $\mathrm{PC}_{71} \mathrm{BM}$ with a concentration of $10 \mathrm{mg} \mathrm{mL}$ (1:1.5) dissolved in chlorobenzene was spin-coated at $1800 \mathrm{rpm}$ on top of the $\mathrm{ZnO}$ films. DIO [3\% (v/v)] was added to the blend solution at least $1 \mathrm{~h}$ before spin coating. The active layer was left to dry in vacuum for $1 \mathrm{~h}$, followed by the evaporation of a thin $\mathrm{MoO}_{3}$ layer $(\approx 3$ $\mathrm{nm}$ ) and a $100 \mathrm{~nm}$ thick Ag electrode.

Characterization. The electrical properties of the films were measured using a four-point probe cascade Microtech 44/7 S 2749 station connected to a Keithley 2001 multimeter. Typically, six measurements were performed at different positions on the films, and average values of $R_{\mathrm{S}}$ were calculated. A PerkinElmer lambda 950 spectrometer was used for optical transmission measurements. The surface morphology of the films was determined by employing FEISEM and Veeco atomic force microscopy (AFM). Work function measurements were performed by using a Scanning kelvin probe microscope Series 7 from KP Technology.

The PCE of the fabricated solar cells was determined from current density-voltage curve measurements obtained under 1 sun, AM $1.5 \mathrm{G}$ spectrum illumination from a solar simulator (Abet Technologies, model Sun 3000). The solar simulator illumination intensity was monitored using a monocrystal silicon reference cell (Rera Systems) calibrated against a National Renewable Energy Laboratory calibrated reference cell. EQE values were measured using a QEX10 Quantum Efficiency Measurement System (PV Measurements). For EQE measurements, the devices were illuminated using monochromatic light from a xenon lamp passing through a monochromator. A calibrated monosilicon diode with a known spectral response was used as a reference.

Flexibility tests were performed using a two-point bend testing setup connected to a motor driven by an electronic controller allowing the arm to move back and forth along the horizontal direction. 
Correspondingly, the solar cell was bent from 6 to $3 \mathrm{~cm}$ radius of curvature.

\section{RESULTS AND DISCUSSION}

$\mathrm{Ag}$ is chosen as the UTMF for the multilayer TE because of its high transparency in the visible region at thicknesses of $<10 \mathrm{~nm}$ and low electrical resistivity $\left(\rho_{\text {bulk }} \sim 1.59 \times 10^{-8} \Omega \mathrm{m}\right)$. The ultrathin $\mathrm{Ag}$ film was capped with an antireflective thin AZO layer that also protects the underneath metal from oxidation. $\mathrm{TiO}_{2}$ was used as an undercoat layer. It has a relatively high refractive index $(\sim 2.7)$ and high optical transparency (negligible absorption) and thus reduces further the reflection and correspondingly increases the optical transmission of the whole multilayer TE. Besides, $\mathrm{TiO}_{2}$ is an efficient seed layer for $\mathrm{Ag}$ that improves its smoothness and continuity at very low thicknesses, in this way reducing the $R_{\mathrm{S}}$ and the light scattering (haze). Figure 1 shows the proposed TE structure and a picture of the flexible Willow Glass substrate used in this work.

a)

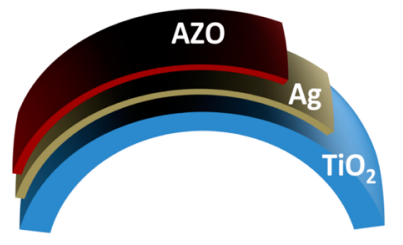

b)

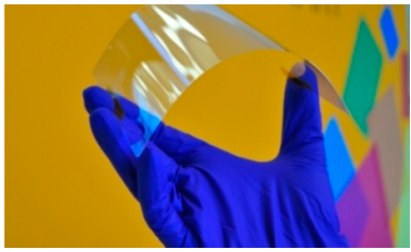

Figure 1. (a) Proposed transparent electrode structure and (b) picture of the flexible Corning Willow Glass substrate.

First, we investigated the effect of Ag midlayer thickness on the electro-optical properties of the multilayer structure. Figure 2a shows the optical transmittance as a function of wavelength a)

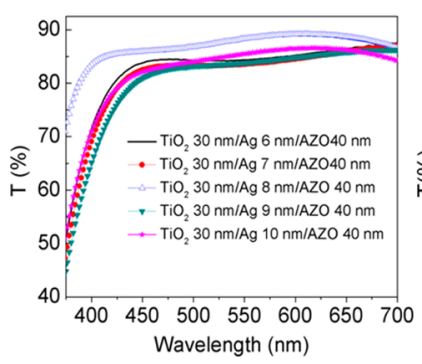

b)

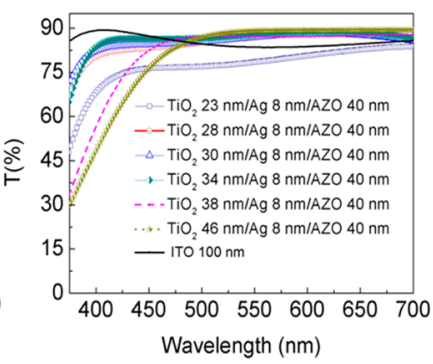

Figure 2. (a) Optical transmittance spectra of $\mathrm{TiO}_{2} 30 \mathrm{~nm} / \mathrm{Ag} x / \mathrm{AZO}$ $40 \mathrm{~nm}$ for different Ag thicknesses. (b) Optical transmittance spectra of $\mathrm{TiO}_{2} x / \mathrm{Ag} 8 \mathrm{~nm} / \mathrm{AZO} 40 \mathrm{~nm}$ for different $\mathrm{TiO}_{2}$ thicknesses compared with the optical spectrum of commercial $100 \mathrm{~nm}$ ITO.

of the multilayer TE for different $\mathrm{Ag}$ thicknesses while the thicknesses of $\mathrm{TiO}_{2}$ and AZO layers, 30 and $40 \mathrm{~nm}$, respectively, are kept constant. At thicknesses of $<8 \mathrm{~nm}$, the $\mathrm{Ag}$ film is more discontinuous (more granular), giving a nonoptimized antireflection effect, more scattering, and plasmonic absorption. For thicknesses of $>8 \mathrm{~nm}$, the intrinsic film absorption starts dominating. There thus exists an optimal thickness $(\sim 8 \mathrm{~nm})$ at which the transmission is higher for most of the wavelength range of interest. It is worth noting that $\mathrm{Ag}$ films become effectively continuous for thicknesses of $>10 \mathrm{~nm}$ on conventional glass substrates. Seeding the metal film growth by depositing an intermediate layer on the substrate can reduce the percolation thickness, i.e., the thickness at which the film goes from a discontinuous to continuous geometry. For example, in a previous work, we had shown that very thin $(\sim 1 \mathrm{~nm}) \mathrm{Cu}$ layers can be used as a seed to make $\mathrm{Ag}$ continuous at very small thicknesses (even $3 \mathrm{~nm}){ }^{59}$ The transition from an aggregated (granular) $\mathrm{Ag}$ film to a continuous film was also investigated by scanning electron microscopy (SEM). Figure 3 shows the SEM images of 5 and 8 a)

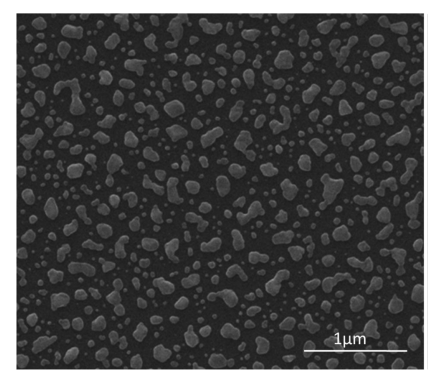

b)

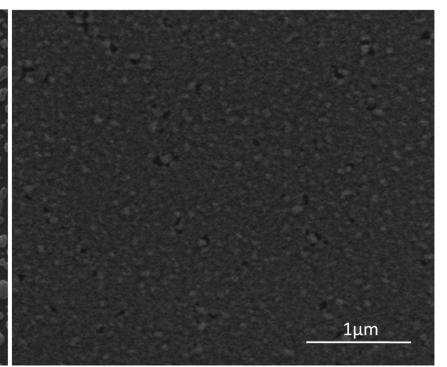

Figure 3. Top-view SEM images showing (a) $5 \mathrm{~nm} \mathrm{Ag}$ and (b) $8 \mathrm{~nm}$ $\mathrm{Ag}$ films deposited on a $30 \mathrm{~nm}$ thick $\mathrm{TiO}_{2}$ layer.

$\mathrm{nm} \mathrm{Ag}$ films atop the $\mathrm{TiO}_{2}$ undercoat layer. The $5 \mathrm{~nm}$ thick film is discontinuous, while the $8 \mathrm{~nm}$ thick $\mathrm{Ag}$ forms a continuous film. This confirms that the $\mathrm{TiO}_{2}$ undercoat layer reduces the percolation thickness of the $\mathrm{Ag}$ film, which becomes completely continuous at $8 \mathrm{~nm}$. In fact, the $\mathrm{TiO}_{2} 30$ $\mathrm{nm} / \mathrm{Ag} 8 \mathrm{~nm} / \mathrm{AZO} 40 \mathrm{~nm}$ multilayer structure exhibits the highest transmittance (average 86\%) in the range of 375-700 $\mathrm{nm}$, together with a very low $R_{\mathrm{S}}$ of $6 \Omega / \mathrm{sq}$ (Table 1 ).

Table 1. $R_{\mathrm{S}}$ and Average Transmittance $\left(T_{\text {vis }}\right)$ Values in the Range of 375-700 nm and of $\mathrm{TiO}_{2} 30 \mathrm{~nm} / \mathrm{Ag} x / \mathrm{AZO} 40 \mathrm{~nm}$ Samples for Different Ag Thicknesses

\begin{tabular}{ccc} 
sample & \multicolumn{1}{c}{$R_{\mathrm{S}}(\Omega / \mathrm{sq})$} & $T_{\text {vis }}(\%)(375-700 \mathrm{~nm})$ \\
$\mathrm{TiO}_{2} 30 \mathrm{~nm} / \mathrm{Ag} 6 \mathrm{~nm} / \mathrm{AZO} 40 \mathrm{~nm}$ & $9.3 \pm 1$ & $82.4 \pm 0.13$ \\
$\mathrm{TiO}_{2} 30 \mathrm{~nm} / \mathrm{Ag} 7 \mathrm{~nm} / \mathrm{AZO} 40 \mathrm{~nm}$ & $7.1 \pm 0.6$ & $81.3 \pm 0.08$ \\
$\mathrm{TiO}_{2} 30 \mathrm{~nm} / \mathrm{Ag} 8 \mathrm{~nm} / \mathrm{AZO} 40 \mathrm{~nm}$ & $6.3 \pm 0.4$ & $86.7 \pm 0.03$ \\
$\mathrm{TiO}_{2} 30 \mathrm{~nm} / \mathrm{Ag} 9 \mathrm{~nm} / \mathrm{AZO} 40 \mathrm{~nm}$ & $5 \pm 0.1$ & $80.5 \pm 0.04$ \\
$\mathrm{TiO}_{2} 30 \mathrm{~nm} / \mathrm{Ag} 10 \mathrm{~nm} / \mathrm{AZO} 40 \mathrm{~nm}$ & $4.2 \pm 0.2$ & $82.2 \pm 0.02$
\end{tabular}

Considering that in our case $R_{\mathrm{AZO}}$ and $R_{\mathrm{TiO}_{2}} \gg R_{\mathrm{Ag}}$, the overall $R_{\mathrm{S}}$ is mainly given by the $\mathrm{Ag}$ film. By keeping constant the $\mathrm{Ag}$ and AZO thicknesses of 8 and $40 \mathrm{~nm}$, respectively, we optimized the $\mathrm{TiO}_{2}$ bottom layer thickness, by varying it from 23 to $46 \mathrm{~nm}$. From Figure $2 \mathrm{~b}$ and Table 2, one can see that a 34 $\mathrm{nm} \mathrm{TiO}_{2}$ undercoat layer provided the optimal transmittance (average of $87.66 \%$ ).

The surface morphology of the optimized multilayer TE structure was measured using AFM (Figure 4a). The relatively low surface roughness [root-mean-square (rms) value of 1.3 $\mathrm{nm}$ ] makes the proposed TE structure suitable for PSCs. ${ }^{59}$ Before the PSC's layers had been deposited, surface treatments were usually employed to obtain an optimal morphology of the blend that improves the cell's performance. Annealing steps such as thermal or solvent treatments on polymer-based systems result in two main structural evolutions: crystallization and phase separation, including coarsening, which has already been investigated for many different systems. ${ }^{60,61}$ In our case, prior to the PSC fabrication, the proposed multilayer TEs were 
Table 2. Average Transmittance $\left(T_{\text {vis }}\right)$ Values in the Range of $375-700 \mathrm{~nm}$ of $\mathrm{TiO}_{2} x / \mathrm{Ag} 8 \mathrm{~nm} / \mathrm{AZO} 40 \mathrm{~nm}$ Samples for Different $\mathrm{TiO}_{2}$ Thicknesses and a Commercial $100 \mathrm{~nm}$ ITO Film

\begin{tabular}{lc}
\multicolumn{1}{c}{ sample } & $T_{\text {vis }}(\%)(375-700 \mathrm{~nm})$ \\
$\mathrm{TiO}_{2} 23 \mathrm{~nm} / \mathrm{Ag} 8 \mathrm{~nm} / \mathrm{AZO} 40 \mathrm{~nm}$ & $78.4 \pm 0.10$ \\
$\mathrm{TiO}_{2} 27.8 \mathrm{~nm} / \mathrm{Ag} 8 \mathrm{~nm} / \mathrm{AZO} 40 \mathrm{~nm}$ & $86.3 \pm 0.02$ \\
$\mathrm{TiO}_{2} 30 \mathrm{~nm} / \mathrm{Ag} 8 \mathrm{~nm} / \mathrm{AZO} 40 \mathrm{~nm}$ & $86.6 \pm 0.02$ \\
$\mathrm{TiO}_{2} 34 \mathrm{~nm} / \mathrm{Ag} 8 \mathrm{~nm} / \mathrm{AZO} 40 \mathrm{~nm}$ & $87.7 \pm 0.03$ \\
$\mathrm{TiO}_{2} 38.7 / \mathrm{Ag} 8 \mathrm{~nm} / \mathrm{AZO} 40 \mathrm{~nm}$ & $82.4 \pm 0.08$ \\
$\mathrm{TiO}_{2} 46 . \mathrm{nm} / \mathrm{Ag} 8 \mathrm{~nm} / \mathrm{AZO} 40 \mathrm{~nm}$ & $81.8 \pm 0.12$ \\
$\mathrm{ITO} 100 \mathrm{~nm}$ & $84.9 \pm 0.02$ \\
\hline
\end{tabular}

a)

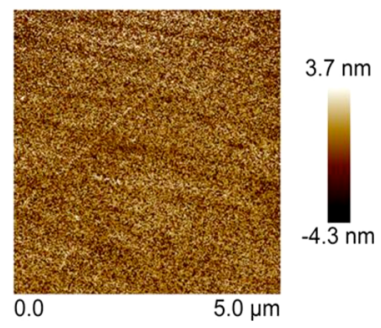

b)

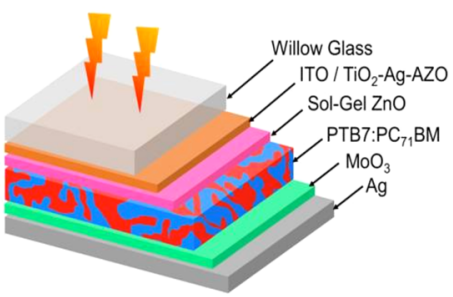

Figure 4. (a) AFM micrograph of a multilayer $\mathrm{TiO}_{2} 34 \mathrm{~nm} / \mathrm{Ag} 8 \mathrm{~nm} /$ AZO $40 \mathrm{~nm}$ transparent electrode (top view of a $5 \mu \mathrm{m} \times 5 \mu \mathrm{m}$ area). (b) Structure of the fabricated polymer solar cell.

subjected to an annealing treatment from room temperature to $150{ }^{\circ} \mathrm{C}$ for $10-15 \mathrm{~min}$ to evaluate their thermal stability. This temperature range provides the optimal annealing steps for improving the morphology of some blends. No measurable variations were observed in the optical transmittance and sheet resistance of the multilayer TEs, confirming that AZO films as thin as $30-40 \mathrm{~nm}$ act as an excellent protective barrier for the underlying Ag.

To estimate the adhesion of the structure to the substrate, we conducted pull tests using standard Scotch tape. The tests are highly qualitative but allow us to avoid films with poor adhesion upon which to build devices. ${ }^{39}$ For all the tested samples, the structure always remains on the surface practically unaltered, indicating good adhesion to the substrate. We also measured the work function of the multilayer electrode, and its value of $5.11 \mathrm{eV}$ was very close to that of a reference ITO $(5.12 \mathrm{eV})$.

The $\mathrm{TiO}_{2} / \mathrm{Ag} / \mathrm{AZO}$-based TEs were incorporated into PSC devices with the flexible Willow Glass/ $\mathrm{TiO}_{2} / \mathrm{Ag} / \mathrm{AZO} / \mathrm{ZnO} /$ $\mathrm{PTB} 7: \mathrm{PC}_{71} \mathrm{BM} / \mathrm{MoO}_{3} / \mathrm{Ag}$ configuration (Figure $4 \mathrm{~b}$ ). The active layer was based on a PTB7:PC ${ }_{71} \mathrm{BM}$ film that is a wellcharacterized photoactive material system that constantly shows PCEs of $>6 \%$ when incorporated into PSCs, but with few reports of ITO-free solar cells. The reference devices were made with commercially available ITO-coated $(100 \mathrm{~nm})$ glass substrates with a thickness of $1.1 \mathrm{~mm}^{8}$ This inverted device structure has been shown to have better ambient stability and be compatible with a roll-to-roll coating process. ${ }^{62,63}$ The current density-voltage $(J-V)$ curves together with the external quantum efficiency (EQE) curves of the fabricated devices are shown in Figure 5. Average values with standard deviations of the photovoltaic parameters for the fabricated devices are listed in Table 3. In parentheses are depicted the results of the best device within several devices.

Compared with its ITO counterparts, the PSCs based on $\mathrm{TiO}_{2} / \mathrm{Ag} / \mathrm{AZO}$ show a similar open circuit voltage $\left(V_{\mathrm{OC}}\right)$, an a)

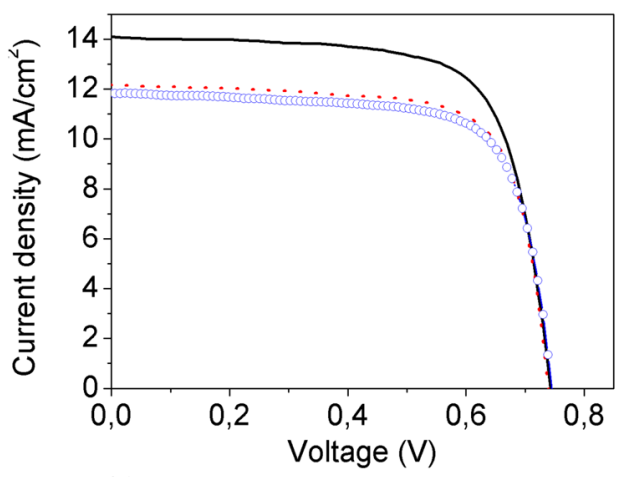

b)

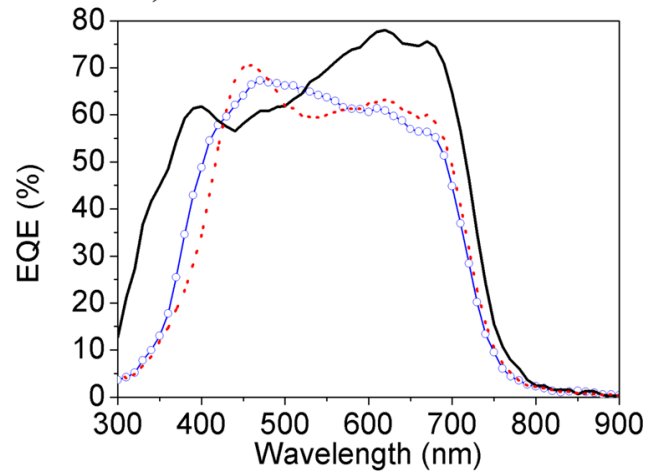

Figure 5. (a) $J-V$ curves and (b) EQE curves of (black line) an ITO reference device, (blue circles) a $\mathrm{TiO}_{2} 46.4 \mathrm{~nm} / \mathrm{Ag} 8 \mathrm{~nm} / \mathrm{AZO} 40 \mathrm{~nm}$ electrode, and (red dots) a $\mathrm{TiO}_{2} 34 \mathrm{~nm} / \mathrm{Ag} 8 \mathrm{~nm} / \mathrm{AZO} 40 \mathrm{~nm}$ electrode.

enhanced fill factor (FF), and a lower photocurrent. The similar $V_{\mathrm{OC}}$ demonstrates that there is a good Ohmic contact between the trilayer electrode and the electron-transporting layer, as expected from the kelvin probe measurement. An enhanced FF reflects the improved $R_{S}$ of the trilayer electrode, while the reduced photocurrent is evident from the IV and EQE curves, where the devices on trilayer electrodes remain below the reference at long wavelengths where the photon flux is higher. Further optical optimization of the TE may lead to an increase in the photocurrent and overcome the efficiencies of ITO-based devices. All these factors contributed to achieving a PCE of $6.6 \%$, more than $85 \%$ of that of the ITO reference device, clearly indicating that the proposed electrode is a competitive alternative to ITO.

To evaluate the mechanical flexibility of the fabricated device on flexible glass substrate incorporating the trilayer TE, we measured the PSC parameters as a function of the bending radii and after multiple cycles in a two-point bend configuration. Figure 6 shows a picture illustrating the bending capability, while Figure 7 shows the average photovoltaic parameters normalized to the flat geometry (no bending) for different radii of curvature, with error bars representing the standard deviation within the measured samples. The maximal bending strain applied to the substrate was approximately $0.16 \%$, calculated from the equation $\varepsilon=h_{\mathrm{S}} /(2 R)$, where $h_{S}$ is the thickness of the flexible glass substrate and $R$ is the minimal bending radius. ${ }^{64}$ When the bending radius is decreased from 6 to $3 \mathrm{~cm}$, the $V_{\mathrm{OC}}$ and short circuit current $\left(J_{\mathrm{SC}}\right)$ do not change significantly, always above $95 \%$ of the flat geometry values. The FF also is subjected to similar changes but with a fluctuating behavior for 
Table 3. Average Solar Cell Parameters and Standard Deviations for $\mathrm{TiO}_{2} x / \mathrm{Ag} 8 \mathrm{~nm} / \mathrm{AZO} 40 \mathrm{~nm}$ Samples Compared with Those of an ITO Reference ${ }^{a}$

\begin{tabular}{|c|c|c|c|c|}
\hline cell & $J_{\mathrm{SC}}\left(\mathrm{mA} / \mathrm{cm}^{2}\right)$ & $V_{\mathrm{OC}}(\mathrm{mV})$ & $\mathrm{FF}(\%)$ & PCE (\%) \\
\hline reference ITO/glass substrate & $14.1 \pm 0.12(14.3)$ & $751 \pm 4.73(754.7)$ & $70.1 \pm 0.78(69.9)$ & $7.4 \pm 0.10(7.5)$ \\
\hline $\mathrm{TiO}_{2} 46 \mathrm{~nm} / \mathrm{Ag} 8 \mathrm{~nm} / \mathrm{AZO} 40 \mathrm{~nm}$ electrode & $11.6 \pm 0.15(11.82)$ & $744.3 \pm 1.64(745.3)$ & $72 \pm 0.60(72.8)$ & $6.2 \pm 0.13(6.4)$ \\
\hline $\mathrm{TiO}_{2} 34 \mathrm{~nm} / \mathrm{Ag} 8 \mathrm{~nm} / \mathrm{AZO} 40 \mathrm{~nm}$ electrode & $11.94 \pm 0.12(12.15)$ & $737.9 \pm 1.10(738.9)$ & $72.5 \pm 1.10(73.4)$ & $6.39 \pm 0.15(6.6)$ \\
\hline
\end{tabular}

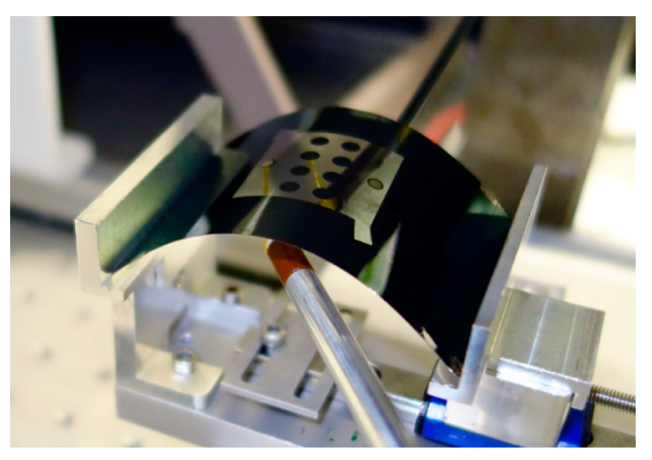

Figure 6. Picture of the $\mathrm{TiO}_{2} / \mathrm{Ag} / \mathrm{AZO}$-based polymer solar cell during the static and cyclic two-point bend testing.

different bending positions (Figure 7b). Most of these unexpected fluctuations can be attributed to changes in the electrical contact of the probes used during the measurements rather than being an intrinsic and systematic device response to bending. Regardless, the negligible change in FF is related to that of the TE's $R_{S}$ (Figure S1 of the Supporting Information). Finally, the PCE, as an overall indicator including all the aforementioned parameters, shows a trend similar to that of FF, with a value that remains clearly above $92 \%$ of that of the reference flat sample for all bending radii.
Performances as a function of the number of bending cycles are shown in Figure 8. Multiple measurements of the same device were used to determine an average value plotted together with the standard deviation as error bars. The maximal and minimal radii were 6 and $3 \mathrm{~cm}$, respectively, and the percentages are relative to the values measured at a $6 \mathrm{~cm}$ bending radius. Figure $8 \mathrm{a}$ shows that $V_{\mathrm{OC}}$ and $J_{\mathrm{SC}}$ decreased only slightly (1\%), while the small decrease in FF indicates that the $R_{\mathrm{S}}$ of the TE increased under continuous bending. Overall, one can see from Figure $8 \mathrm{~b}$ that even after 400 bending cycles the PSC on flexible Willow Glass remains at $94 \%$ of its initial value.

\section{CONCLUSIONS}

We have developed a newly designed $\mathrm{TiO}_{2} / \mathrm{Ag} / \mathrm{AZO}$ trilayer transparent electrode on flexible thin glass sheets and built an ITO-free polymer solar cell upon it. The TE showed a remarkably low roughness, a high optical transmission, and a low electrical sheet resistance, resulting in a measured cell PCE of $6.6 \%$, which is $>85 \%$ of that of a reference cell on a conventional ITO substrate. Flexibility tests on the ITO-free PSC showed its high mechanical robustness under repetitive bending cycles. The proposed multilayer transparent electrode can thus be considered a serious competitor to ITO, in particular for large area roll-to-roll fabrication. The work also a)

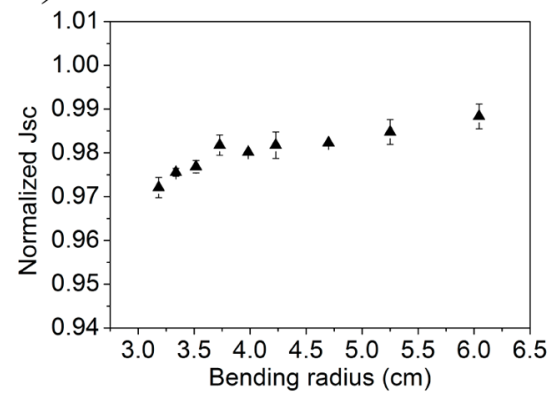

c)

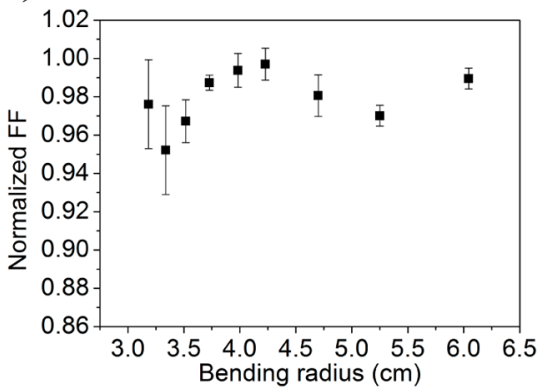

b)

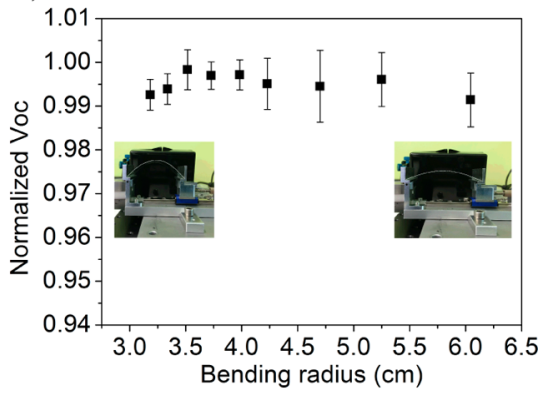

d)

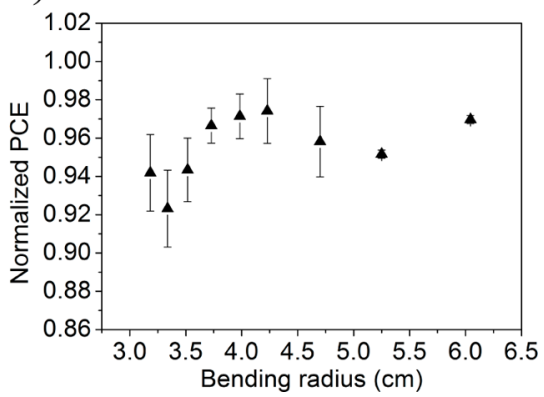

Figure 7. Normalized average values of (a) $J_{\mathrm{SC}},(\mathrm{b}) V_{\mathrm{OC}}$, (c) FF, and (d) PCE as a function of bending radius. The normalized standard deviation is represented with error bars. The insets in panel $b$ show the bending setup at the maximal and minimal bending radii. 
a)

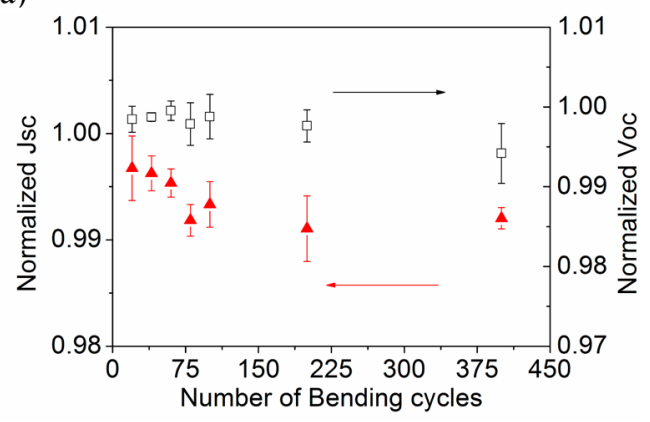

b)

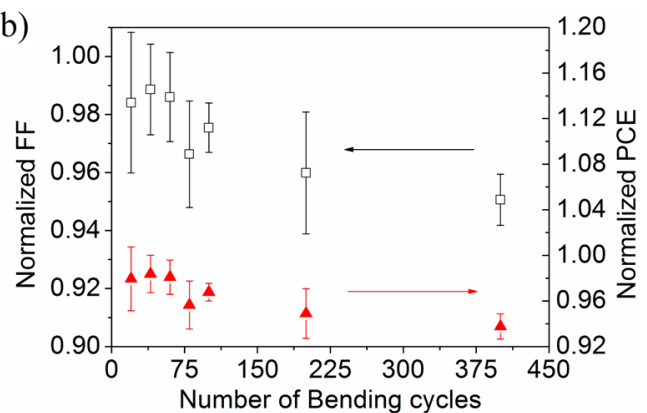

Figure 8. Normalized average values of (a) $J_{\mathrm{SC}}$ and $V_{\mathrm{OC}}$ and (b) FF and PCE taken from multiple measurements of a single device as a function of bending cycle. The normalized standard deviation within the measurements is represented with the error bars.

demonstrates the potential of thin glass with respect to more common polymeric substrates, when one considers its higher surface quality, its impermeability to oxygen and moisture, and the possibility of higher-temperature processing.

\section{ASSOCIATED CONTENT}

\section{S Supporting Information}

Variation of electrical sheet resistance of the developed electrode with different radii of curvature. This material is available free of charge via the Internet at http://pubs.acs.org.

\section{AUTHOR INFORMATION}

\section{Corresponding Author}

*E-mail: dhriti.ghosh@icfo.es.

\section{Author Contributions}

N.F. and P.M.-P. contributed equally to this work.

\section{Notes}

The authors declare no competing financial interest.

\section{ACKNOWLEDGMENTS}

This work was supported by the European Commission through the Erasmus Mundus Joint Doctorate Programme Europhotonics (Grant 159224-1-2009-1-FR-ERA MUNDUSEMJD) and by the Ministerio de Economía y Competitividad via Grants MAT2011-28665 and IPT-2012-0986-120000. We also acknowledge financial support from the Spanish Ministry of Economy and Competitiveness (MINECO) and the "Fondo Europeo de Desarrollo Regional” (FEDER) through Grant TEC2013-46168-R

\section{REFERENCES}

(1) Razykov, T. M.; Ferekides, C. S.; Morel, D.; Stefanakos, E.; Ullal, H. S.; Upadhyaya, H. M. Solar Photovoltaic Electricity: Current Status and Future Prospects. Sol. Energy 2011, 85, 1580-1608.

(2) Brabec, C. J. Organic Photovoltaic: Technology and Market. Sol. Energy Mater. Sol. Cells 2004, 83, 273-292.

(3) Krebs, F. C. Fabrication and Processing of Polymer Solar Cells: A Review of Printing and Coating Techniques. Sol. Energy Mater. Sol. Cells 2009, 93, 394-412.

(4) Shrotriya, V.; Wu, E. H. E.; Li, G.; Yao, Y.; Yang, Y. Efficient Light Harvesting in Multiple Device Stacked Structure for Polymer Solar Cells. Appl. Phys. Lett. 2006, 88, 064104.

(5) Shaheen, S. E.; Brabec, C. J.; Sariciftci, N. S.; Padinger, F.; Fromherz, T.; Hummelen, J. C. 2.5\% Efficient Organic Plastic Solar Cells. Appl. Phys. Lett. 2001, 78, 841-843.

(6) Reyes-Reyes, M.; Kim, K.; Carroll, D. L. High-Efficiency Photovoltaic Devices Based on Annealed Poly(3-hexylthiophene) and 1-(3-methoxycarbonyl)-propyl-1-phenyl-(6,6)C61 Blends. Appl. Phys. Lett. 2005, 87, 083506.

(7) He, Z.; Zhong, C.; Huang, X.; Wong, W.-L.; Wu, H.; Chen, L.; $\mathrm{Su}$, S.; Cao, Y. Simultaneous Enhancement of Open-Circuit Voltage, Short-Circuit Current Density, and Fill Factor in Polymer Solar Cells. Adv. Mater. (Weinheim, Ger.) 2011, 23, 4636-4643.

(8) Liang, Y.; Xu, Z.; Xia, J.; Tsai, S.-T.; Wu, Y.; Li, G.; Ray, C.; Yu, L. For the Bright Future: Bulk Heterojunction Polymer Solar Cells with Power Conversion Efficiency of 7.4\%. Adv. Mater. (Weinheim, Ger.) 2010, 22, E135-E138.

(9) Peet, J.; Kim, J. Y.; Coates, N. E.; Ma, W. L.; Moses, D.; Heeger, A. J.; Bazan, G. C. Efficiency Enhancement of Low-Bandgap Polymer Solar Cells by processing with Alkane Dithiols. Nat. Mater. 2007, 6 , 497-500.

(10) Chen, H.-Y.; Hou, J.; Zhang, S.; Liang, Y.; Yang, G.; Yang, Y.; Yu, L.; Wu, Y.; Li, G. Polymer Solar Cells with Enhanced Open-Circuit Voltage and Efficiency. Nat. Photonics 2009, 3, 649-653.

(11) Hou, J.; Chen, H. Y.; Zhang, S.; Chen, R. I.; Yang, Y.; Wu, Y.; Li, G. Synthesis of a Low Bandgap Polymer and its Application in Highly Efficient Polymer Solar Cells. J. Am. Chem. Soc. 2009, 131, 1558615587.

(12) Hou, J.; Chen, H. Y.; Zhang, S.; Li, G.; Yang, Y. Synthesis, Characterization, and Photovoltaic Properties of a Low Band Gap Polymer Based on Silole-Containing Polythiophenes and 2,1,3Benzothiadiazole. J. Am. Chem. Soc. 2008, 130, 16144-16145.

(13) Li, Z.; Tsang, S.-W.; Du, X.; Scoles, L.; Robertson, G.; Zhang, Y.; Toll, F.; Tao, Y.; Lu, J.; Ding, J. Alternating Copolymers of Cyclopental[2,1-b;3,4-b'] dithiophene and Thieno[3,4-c] Pyrrole-4,6dione for High Performance Solar Cells. Adv. Funct. Mater. 2011, 21, $3331-3336$

(14) Tan, Z.; Zhang, W.; Zhang, Z.; Qian, D.; Huang, Y.; Hou, J.; Li, Y. High-Performance Inverted Polymer Solar Cells with SolutionProcessed Titanium Chelate as Electron-Collecting Layer on ITO Electrode. Adv. Mater. (Weinheim, Ger.) 2012, 24, 1476-1481.

(15) Dou, L.; Hou, J.; Yang, J.; Chen, C. C.; He, Y.; Murase, S.; Moriarty, T.; Emery, K.; Li, G.; Yang, Y. Tandem Polymer Solar Cells featuring a Spectrally Matched Low-Bandgap Polymer. Nat. Photonics 2012, 6, 180-185.

(16) Hendriks, K. H.; Heintges, G. H. L.; Gevaerts, G. S.; Wienk, M. M.; Jansenn, R. A. J. High-Molecular-Weight Regular Alternating Diketopyrrolopyrrolebased Terpolymers for Efficient Organic Solar Cells. Angew. Chem., Int. Ed. 2013, 52, 8341-8344.

(17) Small, C. E.; Chen, S.; Subbiah, J.; Amb, C. M.; Tsang, S.-W.; Lai, T.-H.; Reynolds, J. R.; So, F. High-Efficiency Inverted Dithienogermole-Thienopyrrolodione-Based Polymer Solar Cells. Nat. Photonics 2012, 6, 115-120.

(18) Martínez-Otero, A.; Elias, X.; Betancur, R.; Martorell, J. HighPerformance Polymer Solar Cells Using an Optically Enhanced Architecture. Adv. Opt. Mater. 2013, 1, 37-42.

(19) Krebs, F. C. Polymer Solar Cell Modules Prepared using Rollto-Roll Methods: Knife-Over-Edge Coating, Slot-Die Coating and Screen Printing. Sol. Energy Mater. Sol. Cells 2009, 93, 465-475. 
(20) Blankenburg, L.; Schultheis, K.; Schache, H.; Sensfuss, H. S.; Schrodner, M. Reel-to-Reel Wet Coating as an Efficient Up-Scaling Technique for the Production of Bulk-Heterojunction Polymer Solar Cells. Sol. Energy Mater. Sol. Cells 2009, 93, 476-483.

(21) Medford, A. J.; Lilliedal, M. R.; Jørgensen, M.; Aarø, D.; Pakalski, H.; Fyenbo, J.; Krebs, F. C. Grid-Connected Polymer Solar Panels: Initial Considerations of Cost, Lifetime, and Practicality. Opt. Express 2010, 18, A272-A285.

(22) Krebs, F. C.; Tromholt, T.; Jorgensen, M. Upscaling of Polymer Solar Cell Fabrication using Full Roll-to-Roll Processing. Nanoscale 2010, 2, 873-886.

(23) Han, H.; Adams, D.; Mayer, J. W.; Alford, T. L. Characterization of the Physical and Electrical Properties of Indium Tin Oxide on Polyethylene Napthalate. J. Appl. Phys. 2005, 98, 083705.

(24) Lewis, J.; Grego, S.; Chalamala, B.; Vick, E.; Temple, D. Highly Flexible Transparent Electrodes for Organic Light-Emitting DiodeBased Displays. Appl. Phys. Lett. 2004, 85, 3450-3452.

(25) Chen, Z.; Cotterell, B.; Wang, W.; Guenther, E.; Chua, S.-J. A Mechanical Assessment of Flexible Optoelectronic Devices. Thin Solid Films 2001, 394, 202-206.

(26) Park, S. K.; Han, J. I.; Moon, D. G.; Kim, W. K. Mechanical Stability of Externally Deformed Indium-Tin-Oxide Films on Polymer Substrates. Jpn. J. Appl. Phys., Part 1 2003, 42, 623-629.

(27) Inganäs, O. Organic photovoltaics: Avoiding Indium. Nat. Photonics 2011, 5, 201-202.

(28) Granqvist, C. G. Transparent Conductors as Solar Energy Materials: A Panoramic Review. Sol. Energy Mater. Sol. Cells 2007, 91, $1529-1598$

(29) Kumar, A.; Zhou, C. The Race To Replace Tin-Doped Indium Oxide: Which Material Will Win? ACS Nano 2010, 4, 11-14.

(30) Peng, C.-Y.; Dhakal, T. P.; Garner, S. M.; Cimo, P.; Lu, S.; Westgate, C. Strained Growth of Aluminum-Doped Zinc Oxide on Flexible Glass Substrate and Degradation Studies Under Cyclic Bending Conditions. IEEE Transactions on Device and Materials Reliability 2014, 14, 121-126.

(31) Zhang, F.; Johansson, M.; Andersson, M. R.; Hummelen, J. C.; Inganas, O. Polymer Photovoltaic Cells with Conducting Polymer Anodes. Adv. Mater. (Weinheim, Ger.) 2002, 14, 662-665.

(32) Huang, J.; Miller, P. F.; Wilson, J. S.; de Mello, A. J.; de Mello, J. C.; Bradley, D. D. C. Investigation of the Effects of Doping and PostDeposition Treatments on the Conductivity, Morphology, and Work Function of Poly(3,4-ethylenedioxythiophene)/Poly(Styrene Sulfonate) Films. Adv. Funct. Mater. 2005, 15, 290-296.

(33) Pettersson, L. A. A.; Ghosh, S.; Inganas, O. Optical Anisotropy in Thin Films of Poly(3,4-ethylenedioxythiophene)-Poly(4-styrenesulfonate). Org. Electron. 2002, 3, 143-148.

(34) Crispin, X.; Jakobsson, F. L. E.; Crispin, A.; Grim, P. C. M.; Andersson, P.; Volodin, A.; van Haesendonck, C.; van der Auweraer, M.; Salaneck, W. R.; Berggren, M. The Origin of the High Conductivity of Poly(3,4ethylenedioxythiophene)-Poly(styrenesulfonate) (PEDOT-PSS) Plastic Electrodes. Chem. Mater. 2006, 18, 4354-4360.

(35) Stec, H. M.; Williams, R. J.; Jones, T. S.; Hatton, R. A. Ultra-thin Transparent Au Electrodes for Organic Photovoltaics fabricated using a Mixed Mono-Molecular Nucleation Layer. Adv. Funct. Mater. 2011, 21, 1709-1716.

(36) O’Connor, B.; Haughn, C.; An, K.-H.; Pipe, K. P.; Shtein, M. Transparent and Conductive Electrodes Based on Unpatterned, Thin Metal Films. Appl. Phys. Lett. 2008, 93, 223304.

(37) Salinas, J.-F.; Yip, H. L.; Chueh, C. C.; Li, C. Z.; Maldonado, J. L.; Jen, A. K. Y. Optical Design of Transparent Thin Metal Electrodes to Enhance In-Coupling and Trapping of Light in Flexible Polymer Solar Cells. Adv. Mater. (Weinheim, Ger.) 2012, 24, 6362-6367.

(38) Formica, N.; Ghosh, D. S.; Martinez-Otero, A.; Chen, T. L.; Martorell, J.; Pruneri, V. Ultrathin Oxidized Ti to increase Stability and Smoothness of $\mathrm{Al}$ doped $\mathrm{ZnO}$ Transparent Conductors for High Efficiency Indium-free Polymer Solar Cells. Appl. Phys. Lett. 2013, 103, 183304.
(39) Ghosh, D. S.; Chen, T. L.; Mkhitaryan, V.; Formica, N.; Pruneri, V. Solution Processed Metallic Nanowire based Transparent Electrode capped with a Multifunctional Layer. Appl. Phys. Lett. 2013, 102, 221111.

(40) Zhu, R.; Chung, C.-H.; Cha, K. C.; Yang, W.; Zheng, Y. B.; Zhou, H.; Song, T.-B.; Chen, C. C.; Weiss, P. S.; Li, G.; Yang, Y. Fused Silver Nanowires with Metal Oxide Nanoparticles and Organic Polymers for Highly Transparent Conductors. ACS Nano 2011, 5, 9877-9882.

(41) Aernouts, T.; Vanlaeke, P.; Geens, W.; Poortmans, J.; Heremans, P.; Borghs, S.; Mertens, R.; Andriessen, R.; Leenders, L. Printable Anodes for Flexible Organic Solar Cell Modules. Thin Solid Films 2004, 22-25, 451.

(42) Glatthaar, M.; Niggemann, M.; Zimmermann, B.; Lewer, P.; Riede, M.; Hinsch, A.; Luther, J. Organic Solar Cells using Inverted Layer Sequence. Thin Solid Films 2005, 491, 298-300.

(43) Tvingstedt, K.; Inganas, O. Electrode Grids for ITO Free Organic Photovoltaic Devices. Adv. Mater. (Weinheim, Ger.) 2007, 19, 2893-2897.

(44) Agnieszka, I.; Andrzej, C. Perspectives of Applied Graphene: Polymer Solar Cells. Prog. Polym. Sci. 2012, 37, 1805-1828.

(45) Geim, A. K. Graphene: Status and Prospects. Science 2009, 324, $1530-1534$.

(46) Arco, L. G. D.; Zhang, Y.; Schlenker, C. W.; Ryu, K.; Thompson, M. E.; Zhou, C. W. Continuous, Highly Flexible, and Transparent Graphene Films by Chemical Vapor Deposition for Organic Photovoltaics. ACS Nano 2010, 4, 2865-2873.

(47) Park, H.; Rowehl, J. A.; Kim, K. K.; Bulovic, V.; Kong, J. Doped Graphene Electrodes for Organic Solar Cells. Nanotechnology 2010, 21, $1-6$.

(48) Wang, Y.; Tong, S. W.; Xu, X. F.; Ozyilmaz, B.; Loh, K. P. Interface Engineering of Layer-by-Layer Stacked Graphene Anodes for High-Performance Organic Solar Cells. Adv. Mater. (Weinheim, Ger.) 2011, 23, 1514-1518.

(49) Wee, B.-H.; Hong, J.-D. A Method for Fabricating an Ultrathin Multilayer Film Composed of Poly(p-phenylenevinylene) and Reduced Graphene Oxide on a Plastic Substrate for Flexible Optoelectronic Applications. Adv. Funct. Mater. 2013, 23, 4657-4666.

(50) Yin, Z.; Sun, S.; Salim, T.; Wu, S.; Huang, X.; He, Q.; Ming, Y.; Zhang, L.-H. Organic Photovoltaic Devices Using Highly Flexible Reduced Graphene Oxide Films as Transparent Electrodes. ACS Nano 2010, 4, 5263-5268.

(51) Kymakis, E.; Savva, K.; Stylianakis, M. M.; Fotakis, C.; Stratakis, E. Flexible Organic Photovoltaic Cells with In Situ Nonthermal Photoreduction of Spin-Coated Graphene Oxide Electrodes. Adv. Funct. Mater. 2013, 23, 2742-2749.

(52) Zhao, B.; He, Z.; Cheng, X.; Qin, D.; Yun, M.; Wang, M.; Huang, X.; Wu, J.; Wu, H.; Cao, Y. Flexible Polymer Solar Cells with Power Conversion Efficiency of 8.7\%. J. Mater. Chem. C 2014, 2, 5077-5082.

(53) Ghosh, D. S.; Betancur, R.; Chen, T. L.; Pruneri, V.; Martorell, J. Semi-transparent Metal Electrode of $\mathrm{Cu}-\mathrm{Ni}$ as a Replacement of an ITO in Organic Photovoltaic Cells. Sol. Energy Mater. Sol. Cells 2011, 95, 1228-1231.

(54) Ghosh, D. S.; Chen, T. L.; Pruneri, V. High Figure-of-Merit Ultrathin Metal Transparent Electrodes Incorporating a Conductive Grid. Appl. Phys. Lett. 2010, 96, 091106.

(55) Formica, N.; Ghosh, D. S.; Chen, T. L.; Eickhoff, C.; Bruder, I.; Pruneri, V. Highly Stable $\mathrm{Ag}-\mathrm{Ni}$ based Transparent Electrodes on PET Substrates for Flexible Organic Solar Cells. Sol. Energy Mater. Sol. Cells 2012, 107, 63-68.

(56) Guillén, C.; Herrero, J. TCO/Metal/TCO Structures for Energy and Flexible Electronics. Thin Solid Films 2011, 520, 1-17.

(57) Garner, S.; Glaesemann, S.; Li, X. Ultra-Slim Flexible Glass for Roll-to-Roll Electronic Device Fabrication. Appl. Phys. A: Mater. Sci. Process. 2104, 116, 403-407.

(58) Rance, W. L.; Burst, J. M.; Meysing, D. M.; Wolden, C. A.; Reese, M. O.; Gessert, T. A.; Metzger, W. K.; Garner, S.; Cimo, P.; 
Barnes, T. M. 14\%-Efficient Flexible CdTe Solar Cells on Ultra-Thin Glass Substrates. Appl. Phys. Lett. 2014, 104, 143903.

(59) Formica, N.; Ghosh, D. S.; Carrilero, A.; Chen, T. L.; Simpson, R. E.; Pruneri, V. Ultrastable and Atomically Smooth Ultrathin Silver Films Grown on a Copper Seed Layer. ACS Appl. Mater. Interfaces 2013, 5, 3048-3053.

(60) Wang, W.; Song, M.; Bae, T. S.; Park, Y. H.; Kang, Y. C.; Lee, S. G.; Kim, S. Y.; Kim, D. H.; Lee, S.; Min, G.; Lee, G. H.; Kang, J. W.; Yun, J. Transparent Ultrathin Oxygen-Doped Silver Electrodes for Flexible Organic Solar Cells. Adv. Funct. Mater. 2014, 24, 1551-1561.

(61) Khaligh, H. H.; Goldthorpe, I. A. Failure of Silver Nanowire Transparent Electrodes under Current Flow. Nanoscale Res. Lett. 2013, $8,235$.

(62) Hoppe, H.; Sariciftci, N. S. Morphology of Polymer/Fullerene Bulk Heterojunction Solar Cells. J. Mater. Chem. 2006, 16, 45.

(63) Hau, S. K.; Yip, H. L.; Baek, N. S.; Zou, J.; O’Malley, K.; Jen, A. K. Y. Air-Stable Flexible Polymer Solar Cells using Zinc Oxide Nanoparticles as an Electron Selective Layer. Appl. Phys. Lett. 2008, 92, 253301.

(64) Park, S.; Ahn, J. H.; Feng, X.; Wang, S.; Huang, Y.; Rogers, J. A. Theoretical and Experimental Studies of Bending of Inorganic Electronic Materials on Plastic Substrates. Adv. Funct. Mater. 2008, $18,2673-2684$. 